\title{
PROBLEMATIKA SOSIAL PENERAPAN HUKUM ISLAM DI INDONESIA
}

\author{
Norcahyono \\ Universitas Muhammadiyah Palangkarya \\ e-mail: arribangi@gmail.com
}

\begin{abstract}
The application of Islamic law in Indonesia has experienced obstacles since the entry of Western law into Indonesia. So that legal theories were born in response to friction between Western law with Islamic law. Receptie theory emerged as a Dutch strategy for corner and reduce Islamic law in Indonesia. Then, the coming of the theory of Receptie Exit law and Receptio a Contrario legal theory as symbols of resistance to prove that Islamic law still exists in Indonesia. There are two social problems which has a big influence on the application of Islamic law in Indonesia; First: the entry of Western law into Indonesia which intersects with Customary law. Second: Political and cultural influences of the community. In sociological reviews, Islamic law is difficult to be applied in Indonesia, because Islamic law is existed in the area of Religion to territory of the country.
\end{abstract}

Kata Kunci: Sosiologi, Hukum Islam, Indonesia.

\section{PENDAHULUAN}

$S$ istem Hukum di Indonesia dilihat dari perkembangan sejarahnya bersifat majemuk. Ini disebabkan sistem hukum di Indonesia memiliki corak dan susunan sendiri. Sistem yang dimaksud adalah sistem Hukum Adat, sistem Hukum Islam, dan sistem Hukum Barat. Sistem Hukum Adat telah lama ada dan berlaku di Indonesia, walaupun hukum ini dikenal sebagai sistem hukum pada abad ke-20. Hukum Islam telah ada di kepulauan Indonesia sejak orang Islam datang dan bermukim di Nusantara ini. Kesimpulan hasil Seminar di Medan 1963, Islam ke Indonesia pada abad ketujuh/kedelapan Masehi. Pendapat lain mengatakan bahwa Islam baru sampai ke Nusantara ini pada abad ke-13 Masehi (Hossein, 1961: 114). Hukum Barat mulai dikenalkan pemerintah
Belanda pada Tahun 1602 melalui VOC ketika menguasai perdagangan di Indonesia. Awalnya, Hukum Barat itu berlaku bagi orang Eropa saja, namun berjalannya waktu dalam bidang perekonomian dan perdagangan hukum tersebut berlaku juga bagi orang Asia termasuk Indonesia (Wahid, 2013: 115).

Tahun 1945 Hukum Islam di Indonesia mulai memunculkan identitasnya dengan lahirnya perumusan Dasar Negara Piagam Jakarta tanggal 22 Juni 1945. Rumusan Dasar Negara Indonesia adalah "Negara yang berasaskan Ketuhanan dengan menjalankan Syariat Islam bagi pemeluknya". Tetapi atas alasan kemajemukan Agama di Indonesia rumusan dasar dalam Piagam Jakarta tersebut di ganti dengan kata "ketuhanan yang Maha Esa".

Menurut Hazairin perubahan kata dalam Piagam Jakarta menjadi "ketuhanan 
yang Maha Esa" mengandung Norma Hukum yang diatur dalam pasal 29 ayat (1) UUD 1945 bahwa Negara Republik Indonesia berdasarkan atas Ketuhan Yang Maha Esa. Hal itu hanya dapat ditafsirkan antara lain: "Pemeluk Agama Islam wajib menjalankan ajaran syariat Islam, sama halnya Agama-agama lainnya wajib menjalankan agamanya". Tafsir lainnya adalah "Ajaran Agama tidak memerlukan bantuan kekuasaan Negara untuk menjalankannya sebab menjadi kewajiban pribadi terhadap Agamanya masing-masing"(Zainuddin, 2006: 85).

Berdasarkan problematika sosial berlakunya Hukum Islam di Indonesia sebagaimana tergambar di atas, pada akhirnya Hukum Islam dan kekuatannya di akomodasi oleh Pancasila dan UUD 1945. Di antaranya berlakunya undangundang Nomor 1 Tahun 1974 tentang hukum perkawinan Islam. Selain itu lahir Kompilasi Hukum Islam yang berfungsi sebagai pedoman bagi Hakim di Peradilan Agama.

Indonesia sebagai Negara yang memiliki Agama majemuk juga merupakan Negara Hukum, (Arifin, 2009: 52) sehingga untuk menguatkan tatanan kehidupan berbangsa dan bernegara memerlukan aturan hukum (Rule of Law) (Arinanto, 2009: 206). Dalam rangka menguatkan tatanan hukum maka diperlukan suatu sitem yang mengatur hukum tersebut (Achmad, 2009: 204).

Mix Law merupakan sistem hukum yang digunakan di Indonesia, yaitu berlakunya hukum campuran. Sistem hukum ini selain berlakunya hukum perundang-undangan, juga berlaku hukum lain yang diakui dalam UUD 1945 sebagai Konstitusi Negara Indonesia yang telah mengatur kehidupan berbangsa dan bernegara (Tahir, 2007: 150). Selain itu, Kontitusi Negara Indonesia juga mengatur kehidupan beragama, hal ini tercantum dalam alenia keempat pada Pembukaan UUD 1945 yang menyatakan "Ketuhanan yang Maha Esa".

Pada kalimat "Ketuhanan yang Maha $E s a$ " mengandung prinsip pengakuan terhadap keagamaan. Sehingga dapat dibenarkan jika Islam sebagai salahsatu Agama yang diakui di Indonesia, juga diakui eksistensinya sebagai Agama yang resmi dan Hukum Islam sebagai Hukum yang berlaku bagi pemeluknya di Indonesia (Tahir, 2007: 66).

Dari gambaran di atas diperoleh penjelasan bahwa Hukum Islam sudah dikenal dan dijalankan sejak Islam masuk ke Indonesia, namun setelah merdeka keberadaannya untuk menjadi sebuah hukum resmi sebuah Negara terdapat berbagai kendala serta gangguan. Pada tulisan ini penulis membahas tentang "Problematika Sosial Penerapan Hukum Islam di Indonesia".

Adapun bahasan tulisan ini adalah: (1) Apa saja yang menjadi problem sosial penerapan Hukum Islam di Indonesia? (2) Bagaimana tinjauan Sosiologi terhadap penerapan Hukum Islam di Indonesia?

\section{METODE PENELITIAN}

1. Jenis Penelitian

Jenis Penelitian adalah penelitian kepustakaan (library reseach). Dalam penelitian ini membahas dan mengkaji tentang Problematika Sosial Penerapan Hukum Islam di Indonesia melalui berbagai sumber literatur.

2. Sifat penelitian

Penelitian bersifat deskriptif-analitik, yaitu mendeskripsikan problematika dan tinjauan sosial tentang penerapan hukum Islam di Indonesia.

3. Pendekatan Penelitian

Pendekatan yang digunakan ialah pendekatan Sosiologis Historis, Pendekatan 
digunakan untuk mendekati suatu masalah yang terjadi dimasyarakat dengan lebih mementingkan pola-pola hubungan dalam situasi kehidupan sosial.

\section{PROBLEMATIKA SOSIAL PENERAPAN HUKUM ISLAM DI INDONESIA}

Problematika sosial penerapan Hukum Islam di Indonesia pertama: sebab masuknya Hukum Barat ke Indonesia dan sebab bersinggungan dengan Hukum Adat. Kedua: sebab pengaruh politik dan kultur masyarakat.

$$
\text { Untuk membuktikan dua }
$$
problematika sosiologi tersebut penulis menguraikannya sebagaimana berikut:

\section{a. Sebab masuknya Hukum Barat dan Bertentangan dengan Hukum Adat}

Pada waktu Belanda datang ke Indonesia, masyarakatnya menganut Hukum Agama seperti; Hukum Islam, Hindu, Budda dan Nasrani. Selain hukum Agama berlaku juga hukum adat pada masyarakatnya. Menurut C. Snouck Hugronje Kerajaan Islam pada Abad ke 16 sudah ada di Indonesia, diantaranya yaitu Kerajaan Mataram, Banten dan Ciribon (Wahid, 2013: 143).

Belanda yang beragama Kristen Protestan sebagai penjajah memiliki kepentingan untuk bersentuhan dengan permasalahan hukum yang berlaku bagi masyarakat jajahannya. Ketika Belanda masuk ke Indonesia, di masyarakat berlaku Hukum Adat dan Hukum Agama bagi pemeluknya (Usman, 2001: 111). Setelah Belanda memberlakukan Hukum Barat melalui
VOC bagi orang Indonesia pada wilayah hukum tertentu seperti keuangan, perdagangan, dan lapangan ekonomi pada umumnya (Wahid, 2013: 115). Sejak fase inilah mulai terjadi gesekan antara Hukum Barat dengan hukum yang sudah ada di Indonesia yaitu Hukum Agama (Islam) dan Hukum Adat. Untuk memuluskan misinya, Belanda melemahkan eksistensi hukum yang sudah ada dan berlaku bagi masyarakat Indonesia sehingga muncul teori hukum Receptie sebagai rekayasa belanda untuk melemahkan hukum Islam. Teori tersebut ditentang oleh pemerhati Hukum Islam dan Hukum Adat sehingga munculah teori Hukum Receptie Exit dan teori Hukum Receptio A Contrario.

Teori Receptie adalah Teori Hukum yang dipelopori oleh C. Snouck Hurgronje (1857-1936). Snouck merupakan seorang Penasehat Pemerintah Hindia Belanda tentang kajian-kajian Islam di Wilayah Jajahan Belanda. Kemudian Teori Receptie di kembangkan oleh C. Van Vollen dan Betrand Ter Haar Bzn untuk di terapkan di Indonesia. Menurut penganut Teori Receptie Hukum Islam tidak di anggap sebagai hukum jika bertentangan dengan Hukum Adat, Hukum Adatlah yang menentukan berlaku dan tidaknya Hukum Islam (Zainuddin, 2016: 82).

Sebagai contoh pengaruh teori ini yaitu: Hukum Islam yang bersumber dari Alqur'an dan as-Sunnah, hanya sebagian kecil yang mampu dilaksanakan oleh umat Islam dan di akui oleh Negara. Sedangkan Hukum 
Pidana Islam yang bersumber dari Alqur'an dan as-Sunnah tidak mempunyai tempat eksekusi bila hukum dimaksud tidak di undangundang di Indonesia. Selain itu Hukum Islam baru dapat menjadi hukum yang berlaku bagi pemeluknya secara yuridis formal bila hukum itu telah diresmikan sebagai UndangUndang di Indonesia. Namun jika Hukum Islam telah di undangundangkan, pemeluk Islam memiliki pilihan sesuai keinginannya, yaitu bisa memilih antara Hukum Islam atau memilih Hukum Pengadilan Negeri (Zainuddin, 2016: 82).

Sedangkan teori Receptie Exit adalah teori yang digagas Hazairin Tahun 1905 dan dikembangkan secara sistematis oleh murid-muridnya seperti Sajuti Thalib, Muhammad Daud Ali, Bismar Siregar, dan yang lainnya (Zainuddin, 1998: 41).

Teori ini muncul untuk menolak teori Receptie, bahwa teori Receptie harus keluar dari teori hukum Nasional Indonesia karena bertentangan dengan UUD 1945 serta bertentangan dengan Alquran dan sunah Rasul. Hazairin berpendapat bahwa Hukum Islam itu bagi rakyat yang beragama Islam dilaksanakannya sebagai bagian dari perkara imannya (Hazairin, 1974: 101). Lebih lanjut Hazairin menyatakan Teori Receptie di gagas Pemerintahan Belanda untuk menghalangi keberadaan Hukum Islam di Indonesia (Hazairin, 1982: 7). Teori Receptie bagi ahli hukum Indonesia telah mendarah daging, sebab mereka adalah didikan Belanda. Teori Receptie bagi Hazairin adalah Teori Iblis, sebab teori tersebut menentang keimanan orang Islam, menurut Hazairin adalah teori Iblis, karena telah menentang keimanan orang Islam. Akhirnya Hazairin menyimpulkan Teori Receptie yang ditetapkan dalam pasal 134 ayat 2 Indische Staaisregeling sebenarnya telah mati sejak berlakunya UUD 1945 sebagai Konstitusi resmi di Indonesia (Hazairin, 1982: 7).

Teori Receptie Exit memandang berlakunya Hukum Islam tidak bergantung kepada Hukum Adat. Buktinya adalah dengan berlakunya UU No. 1 Tahun 1974 tentang Perkawinan. UU tersebut menerapkan Hukum Islam bagi orang Islam dalam perkara perkawinan. Selain itu dikuatkan dengan Pasal 2 ayat (1), UU No. 7 Tahun 1989 tentang Peradilan Agama. Selanjutnya adanya kompilasi Hukum Islam di Indonesia melalui Instruksi Presiden No. 1 Tahun 1991 (Usman, 2001: 8).

Adapun teori Receptio A Contrario adalah teori hukum yang dipelopori Sayuti Thalib dan merupakan pengembangan dari teori Receptie Exit. Contoh penerapan teori ini adalah kasus perkawinan dan kewarisan di Aceh. Masyarakat Aceh menggunakan Hukum Islam dalam menyelesaikan persoalan perkawinan dan kewarisan, jika ada ketentuan Hukum Adat didalamnya maka boleh dipakai dengan syarat tidak bertentangan dengan Hukum Islam (Wahid, 2013: 150). Contoh lain seperti Suku di Bugis Sulawesi Selatan. Suku ini awalnya menggunakan Hukum Adat dalam praktek kewarisan yaitu antara anak laki-laki dan anak perempuan atas pembagian yang sama besar yaitu bagian lelaki sama dengan perempuan, Istilahnya adalah Sama wae asanna manae atau (1:1). Namun setelah memeluk Agama Islam, Hukum Adat tentang kewarisan (1:1) ditinggalkan dan menggunakan cara Hukum Islam yaitu bagian seorang lelaki sama dengan bagian dua orang perempuan. 
Sehingga di istilahkan dengan ungkapan Manjunjung makkunraie mallempa oroane. Selanjutnya Suku Kaili di Sulawesi Tengah, menurut Hukum Adat pasangan calon pengantin yang ingin menikah salah satu syaratnya adalah meminta Izin kepada Dewan Adat untuk dipercikkan air dari sumber mata air yang bersih. Namun setelah memeluk Islam tatacara Adat tersebut di tinggalkan, kemudian menggunakan tatacara yang sesuai dengan Hukum Islam (Zainuddin, 2006: 83).

Selain beberapa contoh di atas, terdapat ungkapan-ungkapan yang menegaskan tentang hubungan Hukum Adat yang menghormati Hukum Islam. Misalnya Suku Aceh memiliki pepatah "Adek dab Syara' sanda menyanda, Syara' mengato Adek memakai", maksudnya adalah hubungan antara adat dan Hukum Islam sangat erat, saling kuat menguatkan, Hukum Islam menentukan Adat melaksanakan. Pepatah lain dari Suku Minang di Sumatera Barat yang memiliki pepatah "Adat Bersendi Syara', Syara' bersendi Kitabullah", maksudnya adalah Adat bersumber dari Hukum Islam, Hukum Islam bersumber dari Al-Qur'an (Zainuddin, 2006: 83).

Dalam menyikapi persinggungan antara Teori Receptie dengan Teori Receptie Exit Hooker melakukan penelitian di beberapa wilayah di Indonesia, sehingga melahirkan Teori Sinkritisme. Menurut teori ini antara Hukum Adat dan Hukum Islam tidaklah saling menyisihkan, masingmasing hukum tersebut memiliki daya ikat yang sama atau sederajat, sehingga masing-masing hukum tersebut mampu menciptakan kekuatan agar masyarakat menyadari untuk melaksanakannya. Namun, kesamaan derajat antara dua hukum tersebut terkadang tidak searah, sehingga adakalanya mengalami konflik, seperti persinggungan antara Hukum Adat dengan Hukum Islam di Minangkabau. Menurut teori Sinkritisme ini, berlakunya Hukum Adat maupun Hukum Islam disebabkan kesadaran masyarakat untuk melaksanakannya bukan karena mana yang lebih dominan salahsatu dari kedua sistem hukum tersebut (Hooker, 1978: 35).

\section{b. Sebab Pengaruh politik dan Kultur Masyarakat.}

Problematika penerapan Hukum Islam di Indonesia dipengaruhi politik dan Kultur masyarakat. Piagam Jakarta yang merumuskan sila Ketuhanan yang dikenal dengan sebutan tujuh kata yaitu: "dengan kewajiban menjalankan Syariat Islam bagi para pemeluknya". Mendapat reaksi dari Indonesia wilayah Timur yang tidak mau bergabung dengan Negara Kesatuan Republik Indonesia pada tanggal 18 Agustus 1945. Sebab rumusan sila Ketuhanan Pada Piagam Jakarta memberikan kedudukan istimewa kepada salahsatu Agama, sedangkan kondisi di Indonesia memiliki Agama yang plural. Dipagi hari tanggal 18 Agustus 1945, Hatta memanggil empat tokoh Islam dan membicarakan hal itu. Atas 
kesepakatan tokoh Islam serta menjaga keutuhan Negara, Hatta mengusulkan penghapusan tujuh kata pada Piagam Jakarta kepada Sidang Pleno Persiapan Kemerdekaan Indonesia (J.A, 1990: 3).

Berdasarkan pristiwa di atas konsep legeslasi Hukum Islam pada awal persiapan kemerdekaan mengakibatkan respon dari Agama lain sebagai efek politik dari pembentukan Negara Kesatuan Republik Indonesia.

Efek pandangan politik juga terjadi ketika Islam ingin membentuk model legeslasi Hukum Islam dalam rangka menjalankan prinsip agama yang merupakan bagian dari pluralitas di Indonesia. Pandangan politik ini terjadi ketika Rancangan Undangundang Peradilan Agama (RUUPA). Sebagaimana diketahui RUUPA ini berbicara mengenai susunan, kewenangan, dan acara. Sementara itu, kekuasaan RUUPA hanya terbatas pada perkara perkawinan, pembagian waris, wakaf, dan sedekah yang merupakan bagian ibadah umat Islam. Namun, RUUPA ini menimbulkan polemik yang berlangsung selama bulan juni 1989. Polemik ini berbentuk debat dihalaman opini, tajuk rencana, dan berita wawancara (Wahid, 2013: 150).

Polemik yang dimaksud diantaranya adalah tanggapan dan reaksi politis Frans Magis Suseno. Inti reaksi politis Frans ini tergambar pada dua hal yaitu: pertama; apabila Negara menyerahkan sebagian dari peradilannya kepada pihak bukan Negara, misalnya Agama, berarti Negara menyerahkan sebagian kedaulatannya kepada pihak lain sekaligus Negara mengabdikan diri kepada norma manusia yang bukan normanya sendiri. Negara menjadi taat kepada hukum bukan bikinannya sendiri. Itu merupakan pengurangan suatu kedaulatan Negara. Kedua, apabila disamping peradilan Negara terdapat Peradilan Agama, bagaimana kesatuan peradilan dalam wilayah Republik Indonesia dapat dijamin? Padahal kesatuan peradilan merupakan salah satu unsur Konstitutif suatu bangsa.

Jelaslah reaksi Frans Magis Suseno memberikan semacam respon politis yang sangat menyita perhatian untuk dipertimbangkan. Respon itu mengajak para tokoh Islam untuk memikirkan kekhawatiran kelompok non-Islam yang tentu saja wajar dan harus diberikan tempat.

Reaksi politik sebagaimana di atas sangatlah wajar, karena jika melacak sejarah perjalanan Hukum Islam di Indonesia, adanya kehawatiran golongan non-Islam jika konsep Piagam Jakarta akan dijadikan landasan utama yuridis di Indonesia. Dan kekhawatiran mereka jika munculnya percobaan mendirikan Negara Islam oleh Kartosuwiryo, yang terkesan adanya obsesi politik Negara Islam dikalangan penganut garis keras. Akibatnya kebuntuan yang tidak bisa lagi dipecahkan. Presiden Suekarno kemudian menawarkan alternatif baru, kembali kepada UUD 45 (Wahid, 2013: 129-130).

Selain problematika, problematika kultural juga menjadi kendala dalam penerapan Hukum Islam di Indonesia. Pada mulanya secara historis, hukum yang berlaku di Indonesia adalah hukum Islam dengan adat istiadat ditundukkan kedalamnya. Setelah Belanda datang ke Indonesia, sistem Hukum Barat diperkenalkan, sehingga ada dualisme sistem hukum yang saling berhadapan yaitu sistem Hukum Islam dengan sistem Hukum Belanda (Barat). Selanjurnya dengan bantuan para orientalis, pemerintah 
Hindia Belanda berhasil mengangkat kedudukan adat istiadat lokal masyarakat yang kemudian di identivikasi sebagai sebagai sistem Hukum Adat dan mempertentangkannya dengan sistem Hukum Islam, sambil mengukuhkan kedudukan sistem hukum Barat dalam prakteknya.

Dengan demikian sistem hukum pada masa Hindia Belanda memiliki tingkatan stratafikasi, Hukum Barat berada pada tingkat satu, Hukum Adat tingkat dua, dan Hukum Islam tingkat tiga. Akibatnya Hukum Islam selalu di identifikasikan dalam posisi yang berlawanan dengan Hukum Adat dan Hukum Barat. Setelah Indonesia merdeka kedua warisan hukum yang terakhir itulah yang diterjemahkan menjadi Hukum Nasional, sehingga kultural Hukum Islam tetap kelas tiga karena menjadi marginal dalam konteks sistem Hukum Nasional.

Sampai sekarang, masih ada problem kejiwaaan yang besar dikalangan umat Islam dalam memahami apa yang disebut hukum Nasional yang berbentuk undang undang resmi. Misalnya UU No. 1 tahun 1974, lahirnya undang-undang ini adalah usaha dari umat Islam yang isinya cerminan dari hukum fikih tetapi masih sulit untuk diterima dan di anggap sebagai hukum Islam. Alasan adalah pertama; hukum perkawinan dalam undang-undang ini tidak disebut Hukum Perkawinan Islam, kedua, karena ada bagian-bagian tertentu dari ketentuan undangundang ini berbeda dan bertentangan dengan hukum fikih tradisional. Oleh karena itu, keragaman hukum fikih yang terdapat dalam kitab- kitab fikih, juga keragaman pendapat para ulama di Indonesia, berdampak sendiri pada dipertentangkannya sebagian undangundang perkawinan. (Jimly, 1990: 14).

Diantara contoh dari keragaman persepsi tentang keberadaan Hukum Islam di Indonesia, ketika menjelang diterapkannya UU tentang Peradilan Agama tahun 1988-1989, ada salah satu Ormas Islam menulis surat resmi kepada tim pengkajian RUU Peradilan Agama Majelis Ulama Indonesia, untuk merekomendasikan usul sebagai kewenangan Peradilan Agama untuk menetapkan putusan perkawinan. Kewenangan Peradilan Agama, menurut bunyi surat itu, harus terbatas hanya pada administrasi saja, sedangkan jatuhnya talak tidak harus dilakukan di hadapan Hakim. Alasannya karena demikianlah dalam aturan hukum Islam (Wahid, 2013: 139).

Selain itu kendala kultur itu datang dari internal pendukung sistem Hukum Islam sendiri, diantaranya masih ada anggapan bahwa Hukum Islam itu merupakan hukum yang final oleh karenanya tidak perlu dikembangkan lagi dengan memasukkan kondisi dan persyaratan baru sebagai bahan pertimbangan dalam mengidentifikasikan sistem Hukum Islam itu. sebagai contoh, salah satu pasal RUU Perkawinan yang mendapatkan kritikan tajam dari para ulama adalah pasal 13 ayat 2 tentang pertunangan. Bunyi pasal tersebut adalah "bila pertunangan itu mengakibatkan kehamilan, maka 
pihak pria diharuskan kawin dengan wanita it, jika disetujui oleh pihak wanita", pasal ini mendapat keritik karena mengandung persepsi bahwa tunangan menjadi syarat bolehnya hubungan seksual antara pihak yang belum melaksanakan akad nikah. (Jaih Mubarak, 2015:39).

Fenomena di atas menunjukkan perbedaan pandangan kultur fiqih yang melemahkan keberadaan Hukum Islam di Indonesia. Bukti lainnya diantaranya adalah masih maraknya terjadi perkawinan dibawah tangan dan banyaknya juga praktek poligami yang tidak tercatat secara resmi di Pengadilan Agama.

\section{TINJAUAN SOSIOLOGI TERHADAP PENERAPAN HUKUM ISLAM DI INDONESIA}

Menerapkan Hukum Islam dalam konteks Negara Kesatuan Republik Indonesia, pada awal kemerdekaan dan sampai saat ini memang terdapat beberapa kendala sosial yang cukup berarti. Setidaknya ada dua persoalan yaitu;

Pertama; Hukum Islam menjadi penengah antara Paradigma Agama dengan Paradigma Negara. Paradigma Agama memandang penerapan Hukum Islam menjadi bagian terpenting dalam melaksanakan totalitas keagamaan, sebab keberadaannya diyakini sebagai Wahyu yang wajib untuk dilaksanakan. Pada sisi lain, penerapan Hukum Islam menjadi bagian dari paradigma Negara yang mempunyai sistemnya sendiri, yaitu sebagai bagian dari Pluralitas Agama di Indonesia. Akibatnya untuk mempertahankan pluralitas itu, Negara terpaksa mereduksi tidak hanya Hukum Islam, tetapi juga berbagai perangkat keIslaman lainnya. Hal ini dilakukan, untuk membuat kelompok non-Islam tetap mengidentifikasikan dirinya dengan Negara. Dalam rangka menghindari kecemburuan sosial dari Agama lain, Negara harus bersikap netral, tidak berpihak kepada salah satu agama.

Berdasarkan tinjauan sosiologi di atas, terjadilah tarik menarik antara prinsip agama dengan prinsip Negara. Solusi dari tarik menarik ini wilayah Publik menjadi tanggungjawab Negara, sedangkan wilayah individu diberikan kepada Agama.

Kedua; Masyarakat Indonesia memiliki Agama Plural, jika Negara mengkhususkan salahsatu agama dari yang lain akan menimbulkan kecemburuan dan keterasingan dari agama lain. Dalam rangka menjaga komitmen pluralitas agama, Negara berkewajiban mereduksi Hukum Islam tujuannya agar meminimalisir kecemburuan dari agama yang lainnya.

Berdasarkan pluralitas agama, penerapan Hukum Islam di Indonesia menjadi ancaman bagi agama lain sehingga kembali kepada UU 45 dan pancasila adalah solusi sosiologis dalam memberikan payung hukum terhadap keragaman Agama tersebut.

Dalam tinjauan Sosiologi, penerapan Hukum Islam di Indonesia seharusnya menawarkan materi hukum yang mengakomodasi masalah-masalah yang disengketakan. Dalam hal ini Hazairin sebagai Ahli Hukum Adat dan Hukum Islam menawarkan konsep tersebut, diantaranya tentang konsep mawali yang terdapat pada Q.S An-Nisa [3] ayat 33.

Menurur Hazairin, perkataan ahli waris pengganti itu tidak ada sangkut pautnya dengan ganti-mengganti ahli waris. Ia hanya menunjukkan siapa yang menjadi ahli waris kalau penghubungnya telah meninggal dunia lebih dulu dari pewaris. Istilah itu terdapat dalam Hukum Adat masyarakat muslim Indonesia. Hazairin mengangkatnya untuk mengisi kekosongan hukum yang 
telah terdapat dalam sistem hukum kewarisan Islam yang telah dianggap mapan mulai Islam masuk ke Indonesia sampai tahun 1960an. Kekosongan itu adalah mengenai kedudukan cucu melalui anak perempuan dalam hukum kewarisan Islam (Hazairin, 1960: 29).

Hukum kewarisan Islam mengenai kedudukan cucu sebagai ahli waris pengganti atau mawali seperti yang ditawarkan Hazairin, ketentuannya digali dari ijtihad atau hasil pemikiran yang mendalam dari para ahli hukum Islam, sehingga mungkin saja terdapat perbedaan pada suatu tempat dengan tempat lainnya. Sebab hasil pemikiran itu, dipengaruhi oleh budaya hukum (legal culture) yang berlaku disuatu tempat atau Negara. Sebagai contoh mengenai kedudukan ahli waris pengganti (mawali) di Indonesia berbeda dengan kedudukan mawali di Negaranegara lainnya seperti Mesir, Suriah, Maroko, Tunisia, dan Pakistan (Zainuddin, 2006: 98).

\section{KESIMPULAN}

Terdapat dua problematika yang berpengaruh besar terhadap penerapan Hukum Islam di Indonesia. Pertama: Sebab masuknya hukum Barat dan sebab bersinggungan dengan Hukum Adat. Kedua: Sebab pengaruh politik dan kultur masyarakat.

Dalam tinjauan Sosiologis, Hukum Islam sulit diterapkan secara sempurna, sebab Hukum Islam berada pada wilayah agama sekaligus di wilayah Negara. Problem sosial tersebut menyebabkan tarik menarik antara prinsip-prinsip agama dengan prinsip-prinsip Negara.
Solusi dari tarik menarik ini Wilayah Publik menjadi tanggungjawab Negara, sedangkan Wilayah individu diberikan kepada Agama. Demikian juga karena pluralitas Agama, maka terkait pemberlakuan Hukum Islam di Indonesia menjadi ancaman bagi agama lain sehingga kembali kepada UU 45 dan pancasila adalah solusi sosiologis dalam memberikan payung hukum terhadap keragaman Agama di Indonesia.

Di tinjau aspek sosiologi, Produk materi Hukum Islam di Indonesia harus mampu mengakomodasi permasalahanpermasalahan yang disengketakan dan bagaimana penyeselaiannya pada masyarakat sederhana dan masyarakat modern.

\section{DAFTAR KEPUSTAKAAN}

Achmad, A. (2009). Menguak Teori Hukum dan Teori Peradilan Termasuk Interpretasi Undang-undang. t.tp: Kencana.

Arifin, H. Z. (2009). Judicial Review di Mahkamah Agung: Tiga Dekade Pengujian Peraturan Perundangundangan. t.tp: Rajawali Pers.

Arinanto, S. (2009). Negara Hukum dalam Perspektif Pancasila, Proceeding Kongres Pancasila: Pancasila dalam berbagai Perspektif. t.tp: Setjen dan Kepanitraan MK.

Hazairin. (1960). Hendak Kemana Hukum Islam. Jakarta: Tintamas.

Hazairin. (1974). Tujuh Serangkai Tentang Hukum. Jakarta: Tintamas Indonesia.

Hazairin. (1982). Hukum Kekeluargaan Nasional (Cet. Ke 3). Jakarta: Tintamas Indonesia. 
Hooker. (1978). Adat Law in Modern Indonesia. Oxford: Oxford University Press.

Hossein, D. (1961). Sejarah Perkembangan Islam di Indonesia. t.tp: Pustaka antarkota.

Jaih Mubarok, (2015). Pembaharuan Hukum Perkawinan di Indonesia. Bandung: Simbiosa Rekatama Media.

J.A, D. (1990). Legeslasi Hukum Islam dan Integrasi Nasional. Jakarta: P3M.

Jimly, A.-S. (1990). Hukum Islam di Indonesia; Delima legeslasi Hukum Agama dan Negara Pancasila. Jakarta: P3M.

Tahir, A. M. (2007). Negara Hukum Suatu Segi Tentang Prinsip-prinsip Dilihat dari Segi Hukum Islam, Implementasinya Pada Negara Madinah dan Masa Kini. t.tp: Kencana.
Usman, S. (2001). Hukum Islam, Asas-asas dan Pengantar Studi Hukum Islam dalam Tata Hukum di Indonesia. Jakarta: Gaya Media Pratama.

Wahid, M. dan A. (2013). Hukum Islam Kontemporer. t.tp: Sinar Grafika.

Zainuddin, A. (1998). Islam Tekstual dan Kontekstual Suatu Kajian Aqidah, Syariah dan Akhlak. Makasar: Yayasan al-Ahkam.

Zainuddin, A. (2006). Hukum Islam Pengantar Ilmu Hukum Islam di Indonesia. Jakarta: Sinar Grafika.

Zainuddin, A. (2016). Sosiologi Hukum. Jakarta: Sinar Grafika. 